\title{
Forecasting the Development of Different Solar Cell Technologies
}

\author{
Arturo Morales-Acevedo and Gaspar Casados-Cruz \\ Electrical Engineering Department, CINVESTAV-IPN, Avenida IPN No. 2508, 07360 Mexico City, DF, Mexico \\ Correspondence should be addressed to Arturo Morales-Acevedo; amorales@solar.cinvestav.mx
}

Received 3 October 2012; Accepted 25 November 2012

Academic Editor: Bhushan Sopori

Copyright (C) 2013 A. Morales-Acevedo and G. Casados-Cruz. This is an open access article distributed under the Creative Commons Attribution License, which permits unrestricted use, distribution, and reproduction in any medium, provided the original work is properly cited.

\begin{abstract}
Solar cells are made of several materials and device structures with the main goal of having maximum efficiency at low cost. Some types of solar cells have shown a rapid efficiency progress whereas others seem to remain constant as a consequence of different factors such as the technological and economic ones. Using information published by the National Renewable Energy Laboratory (NREL) about the increase of solar cells record efficiency, we apply a simple mathematical model to estimate the evolution in the near future for the different cell technologies. Here, as an example, we use data for solar cells made with representative materials and structures of each of the three "PV generations."
\end{abstract}

\section{Introduction}

The photovoltaic effect was discovered by Becquerel in 1839, but it was until the 1950s that a semiconductor device for converting sunlight energy into electrical energy was developed. Since then, such devices have evolved, and nowadays solar cells are made of different materials and structures. Although most of the semiconductor materials exhibit the photovoltaic effect, they should have a bandgap greater than $1.0 \mathrm{eV}$ to be suitable for practical solar cells. The most important parameter of any solar cell is its efficiency, that is, how much of the sunlight energy is converted into electrical energy. Shockley and Queisser established that a single-junction solar cell can reach a maximum efficiency of 30\% [1]. Every year NREL publishes the Best Research-Cell efficiencies data (Figure 1). It contains information about the time evolution of solar cells made of several materials and structures. In this plot we can observe that some types of solar cells have a progressive development ( $\mathrm{CuInGaSe} \mathrm{S}_{2}$, while for others it seems that their evolution has stopped (dye-sensitized $\mathrm{TiO}_{2}$ ).

It is important to have a tool for efficiency forecasting since it can help for taking decisions on investment for each developed technology. We think that it is possible to have a single model for predicting the efficiency evolution for all the different solar cells.

For our purposes in this work, we have chosen representative materials of the known three "PV generations."
The first generation corresponds to crystalline silicon (c-Si) solar cells. The second generation refers to cells made from thin films of polycrystalline materials: Cadmium Teluride $(\mathrm{CdTe})$ and Copper-Indium-Gallium-Selenide ( $\mathrm{CuInGaSe}{ }_{2}$ or CIGS). For the third generation we have chosen the multijunction or tandem solar cells to be operated under concentrated sunlight. This is a very promising technology since the reported maximum efficiency is currently above $43 \%$, although they are very sophisticated. In the following sections, first we shall give a brief description of these types of solar cells, and then we will establish the forecasting model and the results obtained for each of the selected technologies.

1.1. $c$-Si. Silicon is one of the more abundant elements in the Earth's crust. The first successful solar cells were made of c-Si, and at first they had efficiencies between $6 \%$ and $10 \%$, and they were used for powering spatial equipments in satellites. The basic structure of this solar cell type is shown in Figure 2. It consists of a single $p-n$ junction. The p-type silicon base is around $300 \mu \mathrm{m}$ thick whereas the n-type emitter is around $100 \mathrm{~nm}$ thick. An antireflection coating layer is deposited over the emitter in order to minimize reflection losses. Metal contacts are placed at the bottom of the cell as a whole layer and at the top as fingers. Approaches for increasing the efficiency include making inverted pyramids at the surface [2], buried contacts, and selective emitters, and so forth. At 


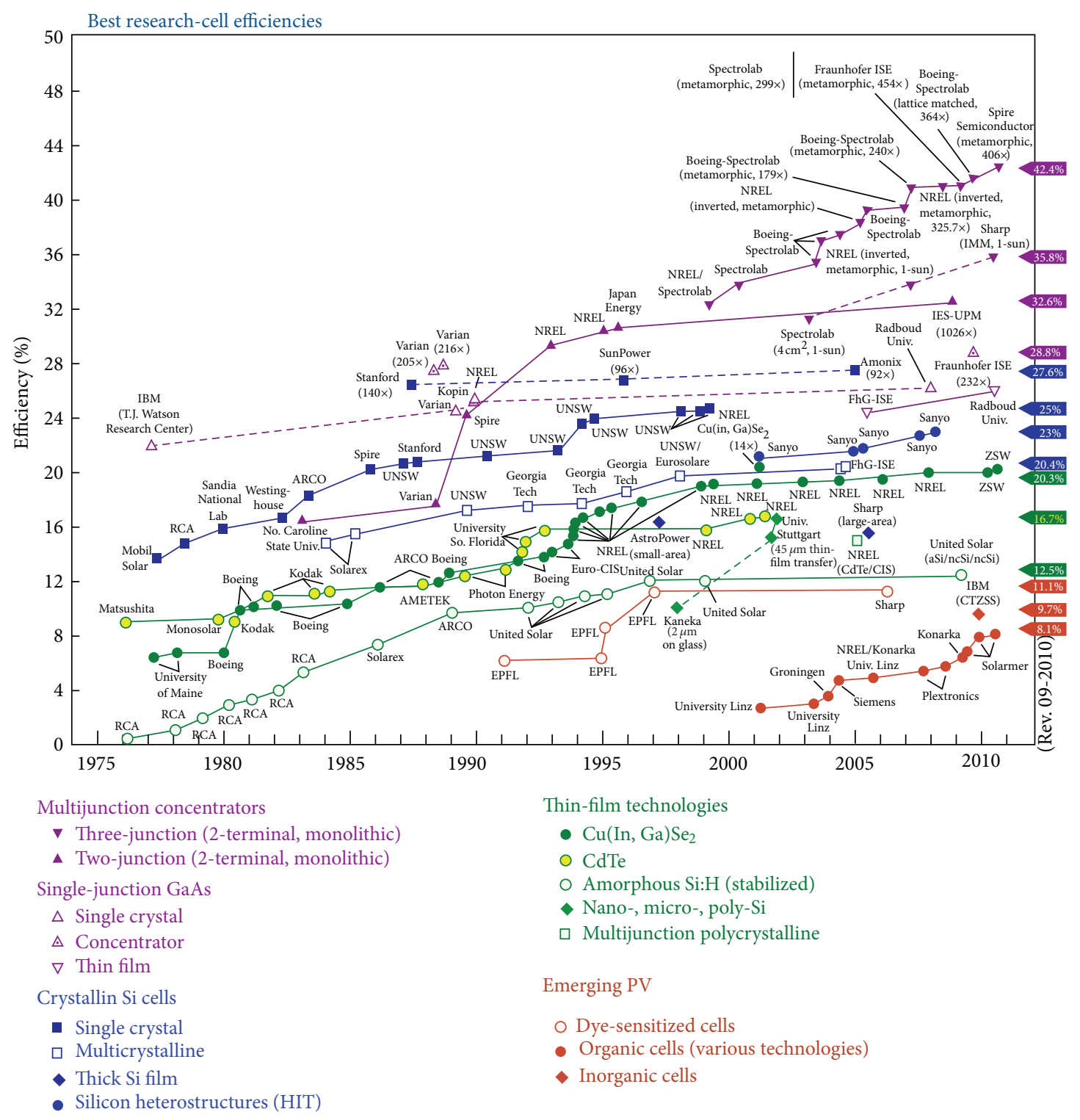

FIGURE 1: NREL's data about record of solar cells efficiencies.

present, c-Si solar cells have reached record efficiencies near $25 \%$, for which the top and bottom surfaces have been well passivated [3].

1.2. CdTe. Cadmium Telluride was synthesized for the first time in 1947; both conductivities $\mathrm{p}$ and $\mathrm{n}$ can be obtained using dopants or by varying the Cd-Te stoichiometry. There are many methods to deposit CdTe for solar cells, and some of them, like spray pyrolysis and screen printing, are very inexpensive. This is the main reason this material became important for the photovoltaic industry. The first CdTe solar cell having a 6\% efficiency was reported in 1963 [4]. The typical structure of a CdTe solar cell is depicted in Figure 3. The efficiency for this solar cell remained unchanged since 2001 (16.5\%) [5], until 2011 when a solar cell manufacturer obtained $17.3 \%$ solar cells [6]. Morales-Acevedo has explained before that the maximum efficiency expected with the current technology for CdTe solar cells is around $18 \%$, unless new structures are developed based on this material [7].

1.3. CuIn $\mathrm{GaSe}_{2}$. Solar cells of this material first were made from $\mathrm{CuInSe}_{2}$ (CIS) because it exhibits interesting properties for solar cells. The first thin film solar cell made of CIS was reported in 1976, and it had an efficiency of $4 \%$ to $5 \%$ [8]. Due to its low bandgap $(1.08 \mathrm{eV})$, indium was replaced by an alloy of indium and gallium which allows varying the material bandgap from 1.08 to $1.68 \mathrm{eV}$ depending upon the [Ga]/[In + $\mathrm{Ga}$ ] ratio. CIGS thin films can be prepared by coevaporation or by selenization of CuInGa layers previously deposited by sputtering. The typical structure of this type of solar cells is shown in Figure 4 . The substrate can be rigid glass, or flexible 


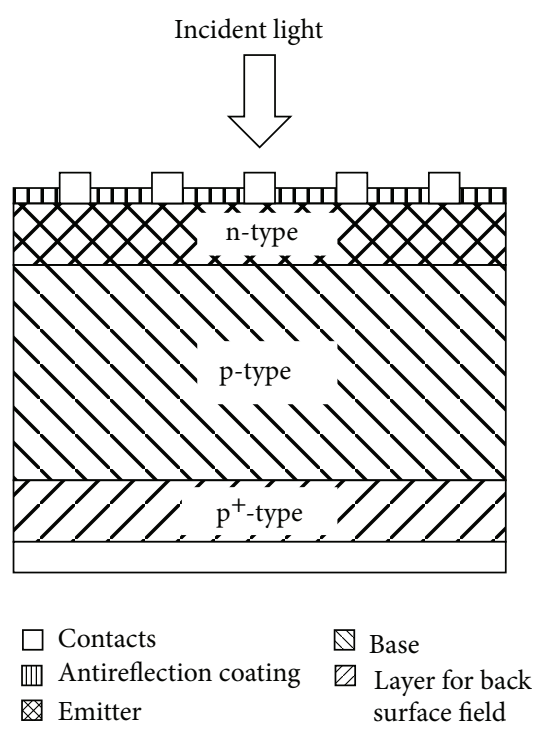

FIgURE 2: Typical silicon solar cell structure.
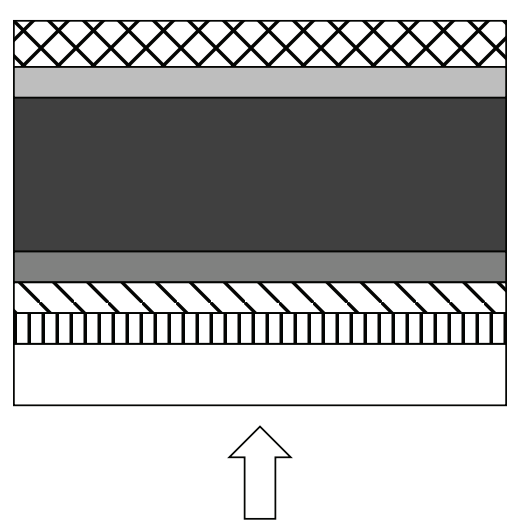

Incident light

$\begin{array}{ll}\otimes \text { Metal } & \square \text { Buffer } \\ \square \text { p }^{+} \text {-Te rich layer } & \text { 典 TCO } \\ \square \text { p-CdTe } & \square \text { Glass } \\ \square \text { n-CdS } & \end{array}$

FIgURE 3: Cadmium Telluride solar cell structure.

like metal foils or plastics. The achieved efficiency depends on the deposition conditions, and improvements have been made changing some of the procedures in the film growth process. This cell has reached a record efficiency of $20.3 \%$ [9].

1.4. Multijunction Solar Cells. The solar cells previously described are single junction, and their maximum efficiency is limited, theoretically, by the material with which they are made, remembering that the bandgap of the absorber layer limits which part of the solar spectrum is absorbed by the device. To overcome this limitation multijunction solar cells have been proposed. Basically it consist of a stack of two or more single junction solar cells with different materials, with the larger bandgap material at the top of the structure and the lower bandgap material at the bottom. These cells are used in space applications, but they represent a promising
Incident light<smiles>C1CCCCC1</smiles>

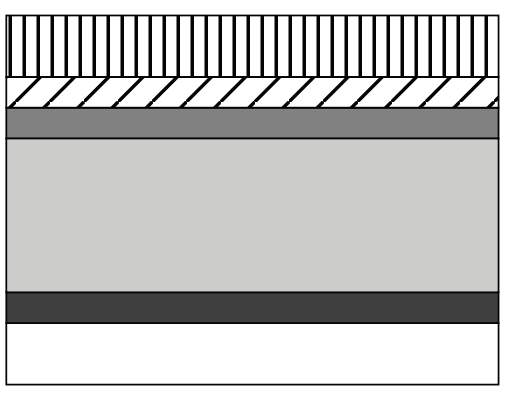
皿 $\mathrm{n}^{+}-\mathrm{ZnO}: \mathrm{Al}$
$\square \mathrm{p}-\mathrm{Cu}(\mathrm{In}, \mathrm{Ga}) \mathrm{Se}_{2}$
$\oslash \mathrm{i}-\mathrm{ZnO}$
$\square$ n-CdS
Back contact (Mo)
$\square$ Substrate

FIgURE 4: CIGS solar cell structure.

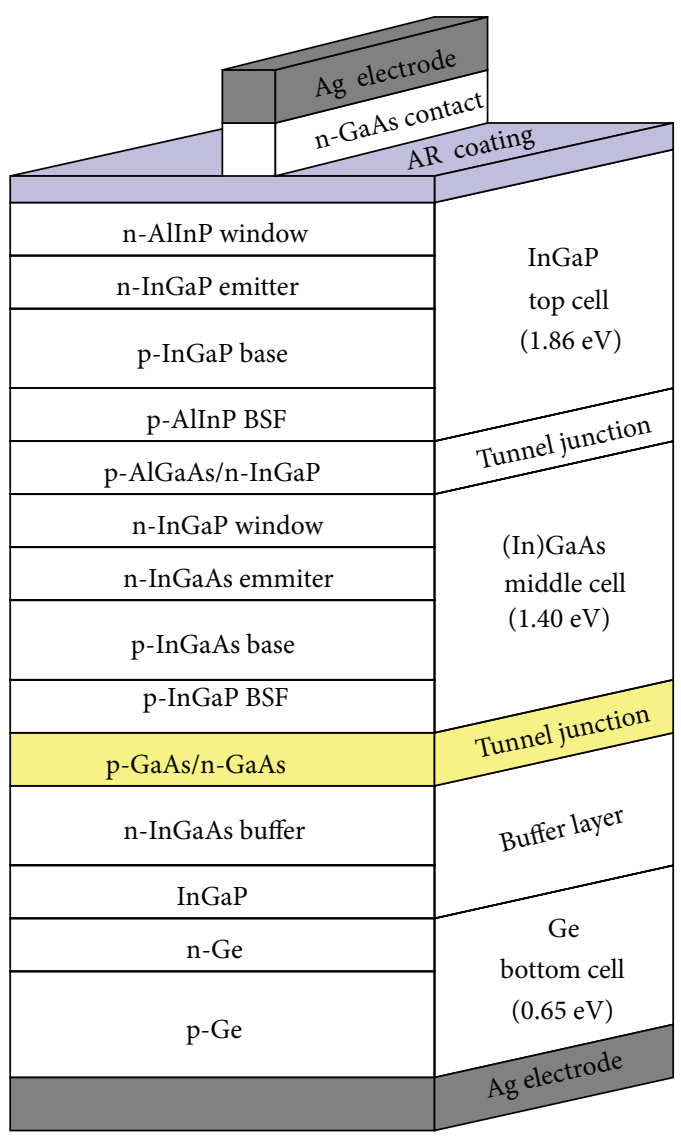

FIgURE 5: Typical multijunction solar cell.

technology for terrestrial applications when combined with solar radiation concentration. The first multijunction solar cell that could overcome the limit for a single junction was reported in 1985 with a value of 34\% [10]. A sketch of a triple junction monolithic solar cell is shown in Figure 5. This particular structure has reached an efficiency of $34.1 \%$ at one 


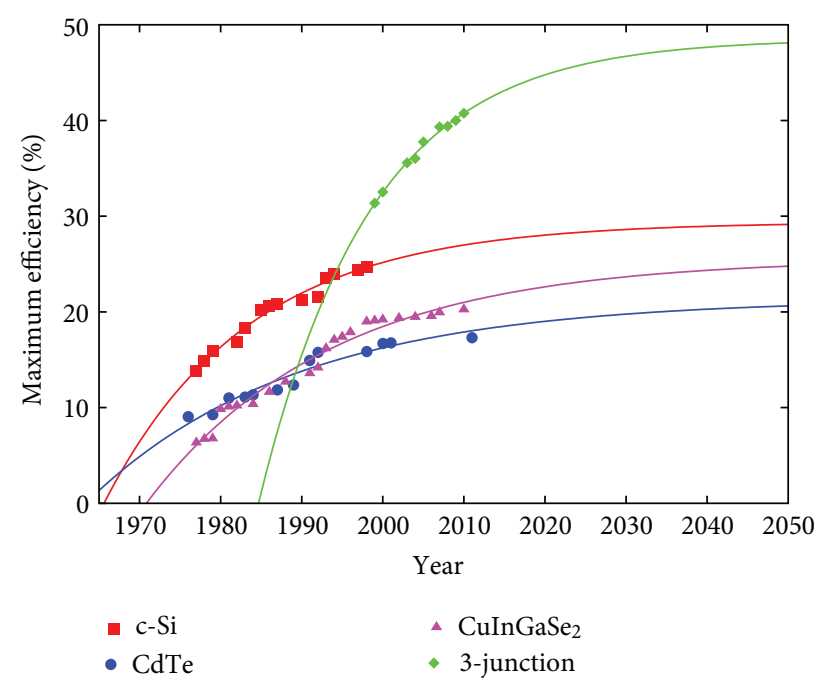

FIGURE 6: NREL's data fitted to proposed forecasting model.

sun and $41.6 \%$ at 364 suns [11], whereas the record efficiency ( $43.5 \%$ at 418 suns) is held by a slightly different structure [12].

\section{The Forecasting Model}

In Figure 1 the NREL plot of the record efficiencies for different solar cells along time is shown. Notice that some types of solar cells change its record efficiency in a relatively short time (e.g., the three-junction solar cell technology). Others, like c-Si and CIGS, currently exhibit a slower record efficiency growth. CIGS solar cells are still under development, but c-Si solar cells seem to have stopped its progress since the year 2000. The slowest development rate for the chosen technologies described previously corresponds to CdTe solar cells which recently (2011) improved their record efficiency from $16.5 \%$ [5] to $17.3 \%$ [6], after 10 years without variation. This behavior suggests a "bound efficiency growth" limited by the open-circuit voltage [7]. First, the increase of short-circuit current density would cause a rapid (linear) efficiency growth, and then further improvement due to the (logarithmic) open-circuit voltage increase would determine the record efficiency. Therefore, we shall use the following function proposed by Goetzberger et al. [13]:

$$
\eta=\eta_{\max }\left(1-\exp \left(\frac{y-y_{0}}{\tau}\right)\right)
$$

where $\eta$ is the cell efficiency (\%) at a given year $y ; y_{0}$ is the year for which significant development began, $\eta_{\max }$ is the maximum efficiency a given solar cell technology would achieve, and $\tau$ is a characteristic time parameter (years) related to the rate of development.

\section{Results and Discussion}

We extracted the data for the selected solar cell types from Figure 1. The reported maximum efficiency every year was taken into account. A least-squares fitting to the proposed
TABLE 1: Model parameters fitting.

\begin{tabular}{lccc}
\hline Cell type & \multicolumn{3}{c}{ Parameter } \\
& $\eta_{\max }(\%)$ & $y_{0}$ (year) & $\tau$ (years) \\
\hline c-Si & $29.4 \pm 2.8$ & $1965 \pm 2.2$ & $17.7 \pm 5.4$ \\
CdTe & $21.4 \pm 3.4$ & $1963 \pm 4.1$ & $25.6 \pm 11.7$ \\
CIGS & $25.6 \pm 2.4$ & $1970 \pm 1.2$ & $22.8 \pm 5.2$ \\
Triple junction & $48.5 \pm 3.9$ & $1984 \pm 2.6$ & $13.8 \pm 4.5$ \\
\hline
\end{tabular}

model was performed using this data. A plot of the fitted function along with the data for the chosen technologies is shown in Figure 6, and the corresponding fitted parameters are summarized in Table 1. These parameters were not restricted for the fitting process, and therefore the results we obtained are related to the information contained implicitly in the data selected for each technology. This is the main reason for having $y_{0}$ different than the real starting year for each technology. For example, it is well known that silicon solar cells began their development around 1954, but the $y_{0}$ year given in Table 1 for these cells is 1965. This is not wrong since the value obtained for $y_{0}$ here can be understood as the year for which development began to be really significant and for which the basic technology for the high efficiencies presently achieved was established. In this regard, the invention of the back surface field, as depicted in Figure 2, was very important and the real silicon solar cell development began after this improvement around 1965.

Other interesting observations can be obtained from the results shown in Table 1. First of all, we can notice that triple-junction solar cells are having a rapid development as compared to the other three technologies. This difference in the evolution velocity is a consequence of both the physical and technological limitations for each kind of solar cell, in addition to the total investment for their research and development. We can notice that solar cells made on polycrystalline materials will reach their maximum (limiting) efficiencies more slowly than those made with crystalline materials since the characteristic time $(\tau)$ is shorter in the latter case.

Notice also that the maximum efficiency predicted for polycrystalline solar cells is far from the $30 \%$ theoretically predicted by Shockley and Queisser [1]. Furthermore, Silicon, $\mathrm{CdTe}$, and CIGS solar cell efficiencies are already very close to their own predicted limit $\left(\eta_{\max }\right)$, and then their future evolution will be very slow. Meanwhile, triple-junction solar cells can still be improved towards the 50\% limit. However, in order to have these (space) kind of solar cells ready for terrestrial applications a great effort is needed in order to develop low-cost solar concentration systems.

Of the technologies considered here, CdS/CdTe solar cells are those for which the minimum efficiency is expected, while the triple junction technology promises the highest efficiency, close to $50 \%$. Then, in the short term, CdTe will keep some market share, but in the long term it might be replaced, first by CIGS solar cells and then by the third generation triple-junction solar cells under concentrated sunlight, when these new technologies become mature enough at production 
level. Silicon solar cells, in the midterm, will maintain an important share of the PV market since their efficiency/cost ratio is still competitive and since this technology continues to be improved due to high production volume and the new developments that are reducing the silicon solar cell cost at industry, despite their efficiency record saturation.

\section{Conclusion}

In this work we have shown that it is possible to use a simple model for solar cell development forecasting. This model allows both the prediction of the maximum expected efficiency and the rate of development. Among the many technologies under development today we have chosen three with great potential for replacing silicon solar cells which is currently the dominant technology in the commercial market. CdTe is the technology for which the minimum efficiency is expected, while the triple-junction technology promises the highest efficiency, close to $50 \%$. Then, in the short term, CdTe will keep some market share, but in the long term it might be replaced, first by CIGS solar cells and then by the third-generation triple-junction solar cells under concentrated sunlight, when these new technologies become mature enough at production level.

\section{Acknowledgment}

This work was supported by CONACyT Project no. 83042 and ICyTDF Project no. 117/2012.

\section{References}

[1] W. Shockley and H. J. Queisser, "Detailed balance limit of efficiency of $p-n$ junction solar cells," Journal of Applied Physics., vol. 32, no. 3, pp. 510-519, 1961.

[2] J. Zhao, A. Wang, P. Altermatt, and M. A. Green, “Twentyfour percent efficient silicon solar cells with double layer antireflection coatings and reduced resistance loss," Applied Physics Letters, vol. 66, pp. 3636-3638, 1995.

[3] T. M. Razykov, C. S. Ferekides, D. Morel, E. Stefanakos, H. S. Ullal, and H. M. Upadhyaya, "Solar photovoltaic electricity: current status and future prospects," Solar Energy, vol. 85, no. 8, pp. 1580-1608, 2011.

[4] D. A. Cusano, "CdTe solar cells and photovoltaic heterojunctions in ii-vi compounds," Solid-Sate Electronics, vol. 6, no. 3, pp. 217-232, 1963.

[5] X. Wu, J. C. Keane, C. DeHart et al., “16.5\% efficient CdS/CdTe polycrystalline thin film solar cell," in Proceedings of the 17th European Photovoltaic Solar Energy Conference, pp. 995-999, Munich, Germany, 2001.

[6] First Solar News Releases, 2011, http://www.firstsolar.com/.

[7] A. Morales-Acevedo, "Thin film CdS/CdTe solar cells: research perspectives," Solar Energy, vol. 80, no. 6, pp. 675-681, 2006.

[8] L. L. Kazmerski, F. R. White, and G. K. Morgan, "Thin-film $\mathrm{CuInSe}_{2} / \mathrm{CdS}$ heterojunction solar cells," Applied Physics Letters, vol. 29, no. 4, pp. 268-270, 1976.

[9] P. Jackson, D. Hariskos, E. Lotter et al., "New world record efficiency for $\mathrm{Cu}(\mathrm{In}, \mathrm{Ga}) \mathrm{Se}_{2}$ thin-film solar cells beyond 20\%," Progress in Photovoltaics, vol. 19, pp. 894-897, 2011.
[10] J. M. Olson, T. Gessert, and M. M. Al-Jassim, "GaInP2/GaAs: a current-and lattice-matched tandem cell with a high theoretical efficiency," in Proceedings of the 18th Photovoltaic Specialist Conference, pp. 552-555, Las Vegas, Nev, USA, 1985.

[11] R. R. King, A. Boca, W. Hong et al., "Band-gap-engineered architectures for high-efficiency multijunction concentrator solar cells," in Proceedings of the 24th European Photovoltaic Solar Energy Conference and Exhibition, Hamburg, Germany, 2009.

[12] Solar Junction Latest News, 2011, http://www.sj-solar.com/.

[13] A. Goetzberger, J. Luther, and G. Willeke, "Solar cells: past, present, future," Solar Energy Materials and Solar Cells, vol. 74, no. 1-4, pp. 1-11, 2002. 

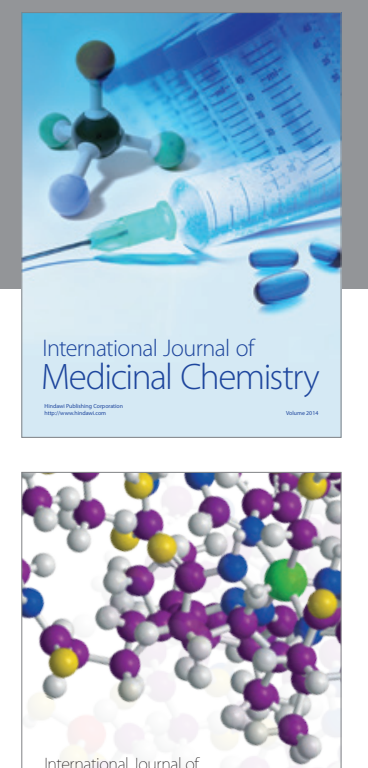

\section{Carbohydrate} Chemistry

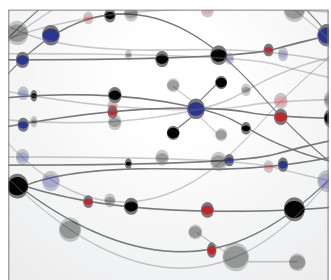

The Scientific World Journal
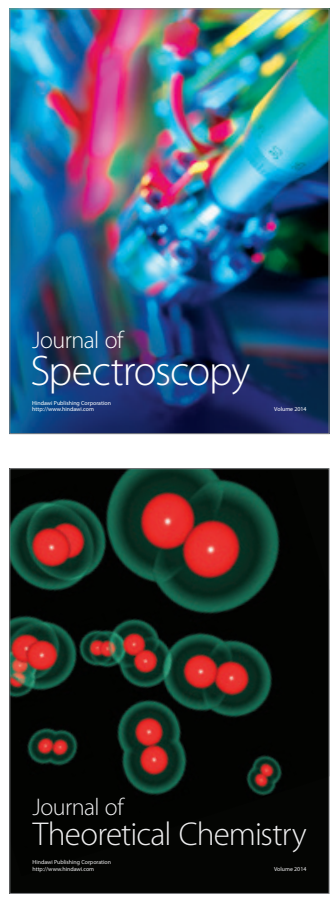
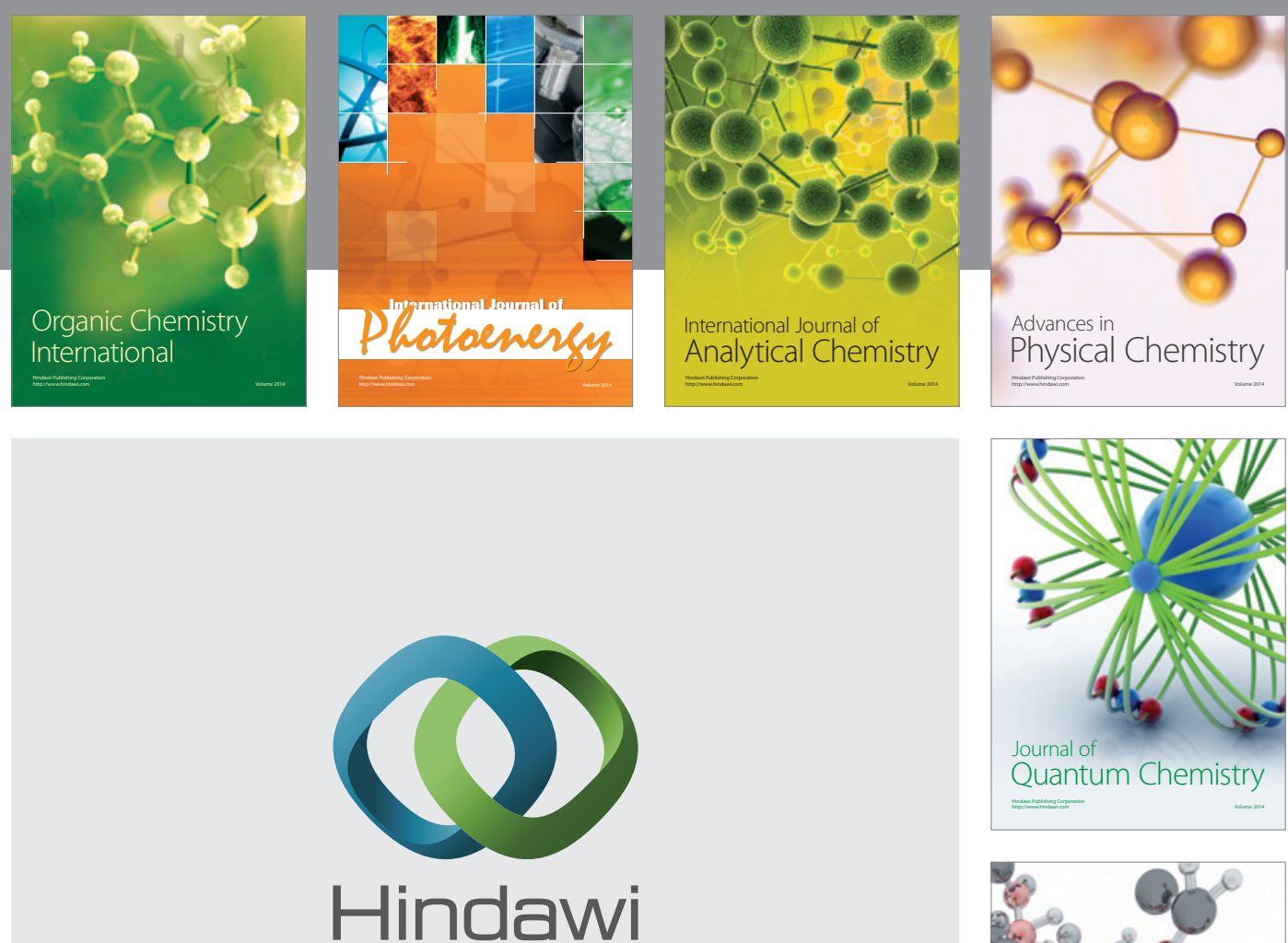

Submit your manuscripts at

http://www.hindawi.com

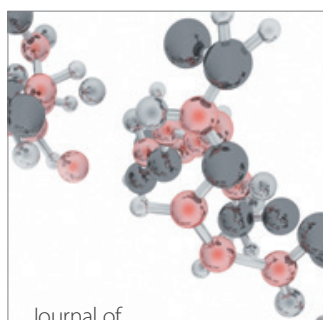

Analytical Methods

in Chemistry

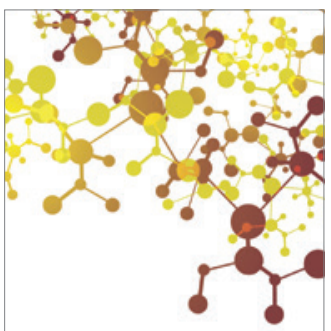

Journal of

Applied Chemistry

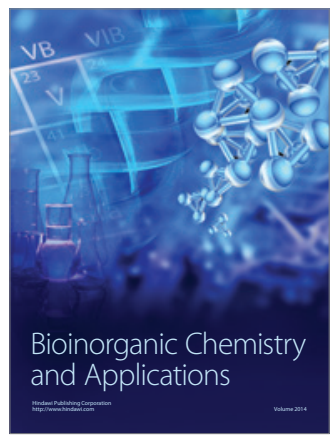

Inorganic Chemistry
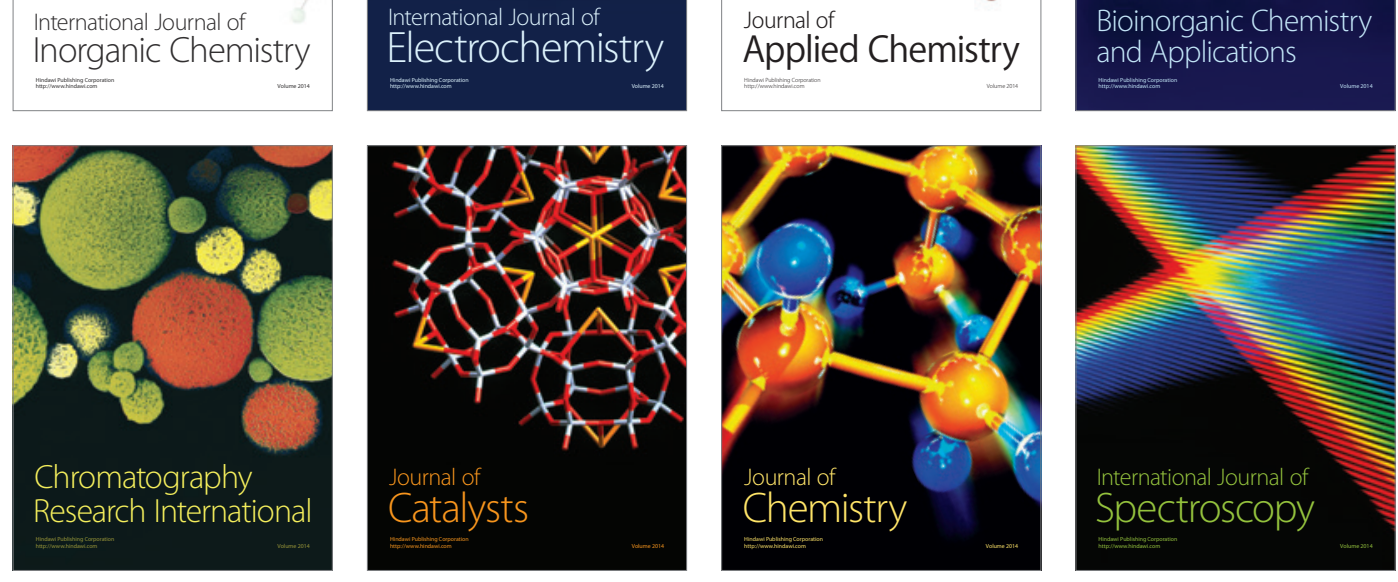